\title{
OPEN Health risk assessment of heavy metals in marine fish to the population in Zhejiang, China
}

\author{
Jian-Long Han, Xiao-Dong Pan ${ }^{\bowtie}$, Qing Chen \& Bai-Fen Huang
}

Environmental pollution with toxic metals can lead to the possible contamination of the marine fish. We investigated the levels of $\mathrm{As}, \mathrm{Cd}, \mathrm{Cr}, \mathrm{Hg}$ and $\mathrm{Pb}$ in 652 marine fish samples (15 species) collected from coastal areas of Zhejiang, China and estimated their health risk. Mean concentrations of $\mathrm{As}, \mathrm{Cd}$, $\mathrm{Cr}, \mathrm{Hg}$ and $\mathrm{Pb}$ were $0.783,0.009,0.114,0.031,0.043 \mathrm{mg} / \mathrm{kg}$ wet weight. The average estimated daily intakes (EDIs) for As, Cd, Cr, Hg and Pb were 1.214, 0.014, 0.177, 0.048 and $0.067 \mu \mathrm{g} / \mathrm{kg}$ bw/day. The risk assessment at mean exposure level showed that there was no health risk associated with these elements through consumption of marine fish. However, potential health risk may exist for high exposure consumers considering the possible contamination of As and $\mathrm{Hg}$. Given that the different levels of certain elements in marine fish in China, this study provides a scientific basis for food safety assessment and suggestions for risk management.

Fish is of great interest for consumers considering its high quality protein, polyunsaturated fatty acids, vitamin$\mathrm{B}$, and other nutrients. However, environmental pollution becomes more and more serious in some coastal and estuarine areas with rapid industry development. Marine organisms can accumulate these contaminants in their muscle tissues and give rise to potential health risk.

Heavy metals have been considered a serious global environmental threat ${ }^{1}$. Marine fish can absorb toxic metals from the surrounding water and sediment as well as through their food ${ }^{2-5}$. For example, Tarley et al. ${ }^{6}$ observed the $\mathrm{Pb}$ with the mean level of $2.15 \mathrm{mg} / \mathrm{kg}$ in canned sardines from Brazil. Ogundiran et al. ${ }^{7}$ found the Cd with mean level of $0.19 \mathrm{mg} / \mathrm{kg}$ in European pilchard from south western Nigeria. Marcotrigiano et al. ${ }^{8}$ reported a high average level of $\mathrm{Hg}(6.53 \mathrm{mg} / \mathrm{kg})$ in spiny dogfish from Italy. Leung et al. ${ }^{9}$ observed level of $\mathrm{Pb}$ $(8.62 \mathrm{mg} / \mathrm{kg})$ in tilapia from Pearl River Delta of China. All these studies indicated that possible contamination of marine fish by heavy metals.

The high exposure of heavy metals and metalloid elements has the confirmative negative effects to human health. Cd, commonly presented as inorganic compounds in the $2^{+}$oxidation state, can cross various biological membranes and lead to neurological disorders, carcinogenic effects and skeletal weakness and defects ${ }^{10}$. Chronic $\mathrm{Hg}$ exposure impacts the pituitary gland and the liver and leads to a compromise of the immune system ${ }^{11} . \mathrm{Pb}$ has been proved to be associated with neurological problems, haematological effects, renal failure, hypertension and cancer ${ }^{12}$. It is therefore reasonable to hypothesize that consumption of marine fish contaminated by heavy metals has the potential health risk.

Zhejiang province, a coastal area of East China Sea, is a rapidly developing region with a high population density, where heavy metal is one of the most important environmental issues ${ }^{13}$. Previous studies have revealed the heavy metal pollution in the soil and nearshore sediments from Zhejiang ${ }^{14-16}$. However, to our knowledge, few studies on the level of heavy metals in marine fish and exposure assessment in Zhejiang have been reported ${ }^{17}$.

The main aims of this study were to analyze heavy metals in marine fish from Zhejiang province and evaluate the health risk based on daily consumption of local residents. The results of our study may provide some insight into heavy metal accumulation in marine fish and serve as a basis for comparison to other regions both in China and worldwide. 


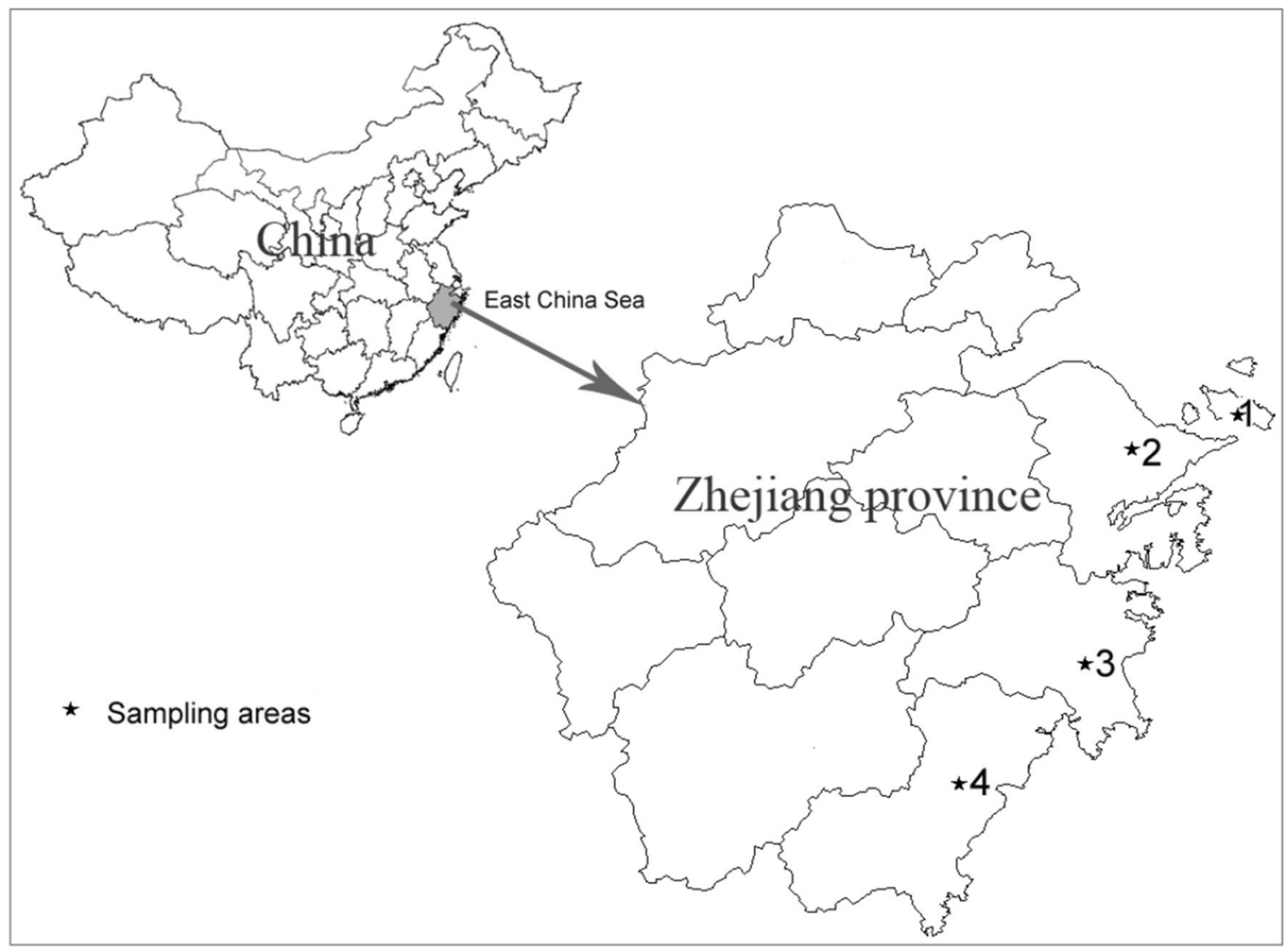

Figure 1. Simple map of the sampling areas of Zhejiang province, China.

\section{Materials and methods}

Sampling and sample preparation. The simple map of sampling place (Zhejiang) was shown in Fig. 1 which was drawn by software of MapGIS K9 SP2 free trial edition (Zondy Cyber Comp., China, http://www. mapgis.com/index.php/index-view-aid-280.html). Total 652 marine fish samples (15 species) were collected at local markets from 2019 to 2020 . Four coastal cities marked by asterisks in Fig. 1 were selected as the sampling areas named by $1,2,3$, and 4 . All samples were collected and refrigerated at $-20{ }^{\circ} \mathrm{C}$ until later analysis in the laboratory. The storage period was no more than 7 days.

Chemical analysis. The concentrations of $\mathrm{As}, \mathrm{Cd}, \mathrm{Cr}, \mathrm{Cu}, \mathrm{Hg}, \mathrm{Ni}$, and $\mathrm{Pb}$ were tested according to the previous report ${ }^{18-20}$. Briefly, samples $(0.5-1.0 \mathrm{~g})$ were digested in acid-clean Teflon vessels containing $6 \mathrm{~mL}$ HNO3 in a Mars-6 microwave digestion system (CEM, Charlotte, NC, USA). The samples in closed vessels were heated at $190{ }^{\circ} \mathrm{C}$ for $20 \mathrm{~min}$. After digestion, the residue was heated at $150{ }^{\circ} \mathrm{C}$ till nearly dry. Then, it was diluted to $20 \mathrm{~mL}$ by ionized water for instrumental analysis. $\mathrm{As}, \mathrm{Cd}, \mathrm{Cr}, \mathrm{Cu}, \mathrm{Hg}, \mathrm{Ni}$, and $\mathrm{Pb}$ in all samples were tested using NexION 300 ICP-MS (Perkin Elmer, Inc., Shelton, CT USA). For quality assurance and quality control purposes, sample blanks, certified reference materials (CRMs), and duplicates of the samples (10\% of the load) were applied in each batch of treated samples. The data used for exposure estimates were according to the recommendation of the report Reliable Evaluation of Low-Level Contaminations of Food issued by WHO ${ }^{21}$. Thus, a value of $1 / 2$ LOD was assigned to all results below the LOD, where the proportion of $<$ LOD results is not $>60 \%$.

Analysis of CRMs. The accuracy of the analytical procedures was verified by analysis of appropriate certificated reference materials (CRMs) using the same digestion and analytical methods. Two CRMs (Table 1) were purchased from National Research Center for Certified Reference Materials, China (NRCCRM). Quantitative results (within $10 \%$ of the certified value) were obtained for each metal in each CRM. Limits of Detection (LODs) were defined as three times the standard deviation of ten runs of blank measurements. LODs of As, Cd, $\mathrm{Cr}, \mathrm{Hg}$ and $\mathrm{Pb}$ were $0.003,0.001,0.005,0.0003$ and $0.004 \mathrm{mg} / \mathrm{kg}$ respectively.

Fish consumption data. The fish consumption data used in this report was extracted from the Food Consumption Survey conducted in Zhejiang province, China in 2008 by the Zhejiang Food and Drug Administration based on our previous reports ${ }^{22-24}$. The representative sample of participants included 9798 people, who were questioned twice about their last 24 -h consumption. The selection of interviewed people and the moment of the interview were chosen in order to obtain a representative consumption profile of the population over 1 year. The estimated fish intake of adult was $108.50 \mathrm{~g} /$ day per person. 


\begin{tabular}{|l|l|l|l|l|}
\hline \multirow{2}{*}{} & \multicolumn{2}{|l|}{ GBW10050 shrimp } & \multicolumn{2}{l|}{ GBW08573 yellow croker } \\
\cline { 2 - 5 } & Certified $(\mathbf{m g} / \mathbf{k g})$ & Measured $(\mathbf{m g} / \mathbf{k g})$ & Certified $(\mathbf{m g} / \mathbf{k g})$ & Measured $(\mathbf{m g} / \mathbf{k g})$ \\
\hline $\mathrm{As}$ & 2.5 & $2.4 \pm 0.4$ & $5.08 \pm 0.39$ & $4.82 \pm 0.66$ \\
\hline $\mathrm{Cd}$ & $0.039 \pm 0.002$ & $0.035 \pm 0.005$ & 0.015 & $0.011 \pm 0.007$ \\
\hline $\mathrm{Hg}$ & $0.049 \pm 0.008$ & $0.051 \pm 0.004$ & $0.169 \pm 0.018$ & $0.155 \pm 0.017$ \\
\hline $\mathrm{Pb}$ & $0.2 \pm 0.05$ & $0.17 \pm 0.07$ & 0.25 & $0.22 \pm 0.09$ \\
\hline $\mathrm{Cr}$ & $0.35 \pm 0.11$ & $0.32 \pm 0.15$ & 0.43 & $0.41 \pm 0.05$ \\
\hline
\end{tabular}

Table 1. Determination of certified reference materials.

\begin{tabular}{|l|l|l|l|l|l|l|}
\hline Elements & $\mathbf{n}$ & Mean $\pm \mathbf{S D}^{\mathbf{a}}$ & $\mathbf{P 9 7 . 5}^{\mathbf{a}}$ & Average range & $\mathbf{M A C}^{\mathbf{b}}$ & No. of $>$ MAC \\
\hline $\mathrm{As}$ & 643 & 0.783 & 3.445 & $0.315-3.172$ & - & - \\
\hline $\mathrm{Cd}$ & 652 & 0.009 & 0.046 & $0.002-0.04$ & 0.1 & 1 \\
\hline $\mathrm{Cr}$ & 189 & 0.114 & 0.391 & $0.016-0.173$ & 2 & 0 \\
\hline $\mathrm{Hg}$ & 650 & 0.031 & 0.138 & $0.009-0.060$ & - & - \\
\hline $\mathrm{Pb}$ & 633 & 0.043 & 0.261 & $0.021-0.082$ & 0.5 & 3 \\
\hline
\end{tabular}

Table 2. The concentration of heavy metals in marine fish from Zhejiang province $(\mathrm{mg} / \mathrm{kg}){ }^{\text {a }}{ }^{2}$ Target analytes with concentrations lower than LOD were treated as one-half of LOD when calculating the mean values; SD, standard deviation. ${ }^{b}$ Maximum allowable concentrations of contaminants in foods.

Exposure estimates. The targeted hazard quotient (THQ) and hazard index (HI) were used to estimate health risk according to US EPA's IRIS database ${ }^{25}$. We used the mean and 97.5 th percentile of obtained elements concentration to represent the consumers with average and high exposure, respectively ${ }^{26}$. The sum of all THQs for each element is referred to as the HI. The formulas are as follows:

$$
\begin{gathered}
\text { Exposure dose }=\frac{C i \times D i \times E d}{B w \times A t} \\
\text { Tageted hazard quotient(THQ) }=\frac{\text { exposure dose }}{R f D} \\
\text { Hazard index }(\mathrm{HI})=\sum_{k=1}^{n=k} \text { targeted hazard quotient }
\end{gathered}
$$

$\mathrm{Ci}$ is the average or P97.5 concentration of the element in the fish $(\mathrm{mg} / \mathrm{kg})$; Di is the daily intake of fish (108.5 g/ capita/day); Ed is the average exposure duration (e.g., 70 years); Bw is the average weight (60 kg for adults and $30 \mathrm{~kg}$ for children); At is the average lifetime (e.g., 70 years). RfD is the oral reference dose ( $\mu \mathrm{g} / \mathrm{kg} / \mathrm{day}, 3$ for As, 0.8 for $\mathrm{Cd}, 3000$ for $\mathrm{Cr}, 0.14$ for $\mathrm{Hg}, 1.5$ for $\mathrm{Pb}$ ); According to US EPA guidelines for assessing conservative risk, $\mathrm{HI}$ were calculated by sum of the THQ. When $\mathrm{HI}<1$, no health risk is expected to occur; If $\mathrm{HI} \geq 1$, there is moderate or high risk for adverse human effects.

Statistical analysis. The statistical analysis was performed by software of Statistical Analysis System (SAS V9.42) (SAS Institute Inc., Cary, NC, USA). Normality and equality of variances of the data were analyzed using Kolmogorov-Smirnov and Levene tests, respectively. Collected data were not normally distributed, and data were transformed into log. One-way analysis of variance (ANOVA) was used to assess whether heavy metals in marine fish and health index $(\mathrm{HI})$ for adults and children varied significantly $(P<0.05)$ in different sampling areas.

\section{Results and discussion}

Heavy metals in marine fishes. Of all fish samples we measured, the highest concentrations of As, Cd, $\mathrm{Cr}, \mathrm{Hg}$ and $\mathrm{Pb}$ were found to be $17,0.76,0.836,0.289$ and $1.48 \mathrm{mg} / \mathrm{kg}$ wet weight, respectively. The mean levels, P97.5 and the range (average levels in different species) were listed in Table 2. The levels of analyzed elements in 15 fish species were presented in Fig. 2. The comparison of these elements in fish with some previous studies was showed in Table 3. The extent of potential pollution in fish can be evaluated by comparing with the maximum allowable concentrations (MAC) recommended by Chinese legislation ${ }^{27}$.

Arsenic (As). Total arsenic concentration in fish varied over a range of $0.005-17 \mathrm{mg} / \mathrm{kg}$ with a mean of $0.783 \mathrm{mg} /$ $\mathrm{kg}$. The result was similar with the study of Liu et al. ${ }^{17}$, who observed $0.325-1.244 \mathrm{mg} / \mathrm{kg}$ in fish samples from 

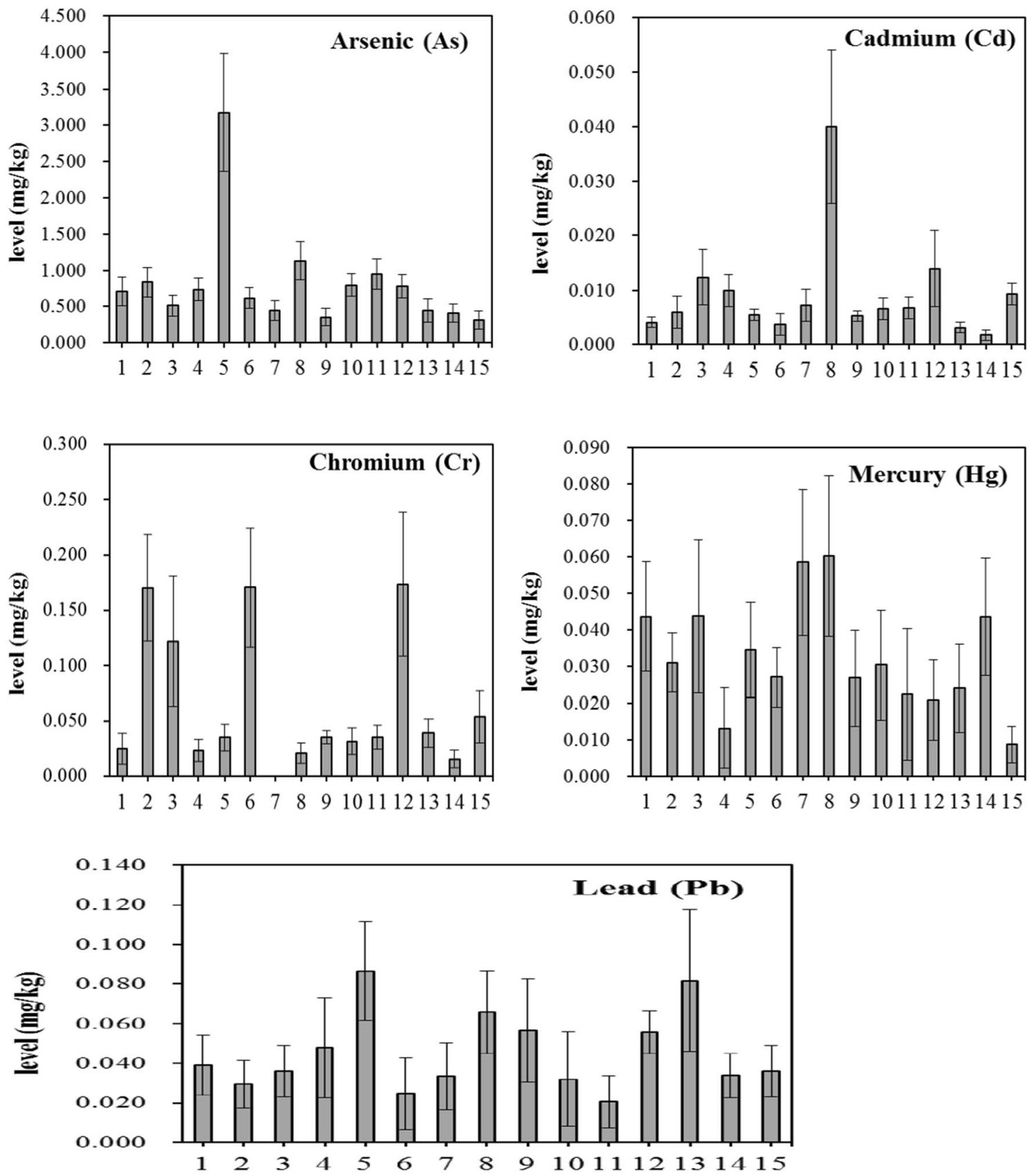

Figure 2. The distribution of the $\mathrm{As}, \mathrm{Cd}, \mathrm{Cr}, \mathrm{Hg}$ and $\mathrm{Pb}$ in marine fish from Zhejiang province, China (mean \pm standard error). 1, Large yellow croaker (Larimichthys crocea); 2, Little Yellow Croaker (Larimichthys polyactis); 3, Largehead hairtail (Trichiurus lepturus); 4, Light maigre (Collichthys lucidus); 5, Flounder

(Pleuronectiformes); 6, Sea bass (Lateolabrax japonicus); 7, Leuciscus waleckii; 8, Pacific saury (Cololabis saira); 9, Miichthys miiuy; 10, Pneumatophorus japonicus; 11, Scomberomorus niphonius; 12, Pomfret (Pampus argenteus); 13, Flathead grey mullet (Mugil cephalus); 14, Bennett (Ilisha elongata); 15, Harpadon nehereus.

East China Sea. Previous reports also found $0.56-23.3 \mathrm{mg} / \mathrm{kg}$ in fish from Croatia ${ }^{28}, 0.4-1.3 \mathrm{mg} / \mathrm{kg}$ in fish from Bangladesh (Dhaka) ${ }^{29}, 1.23-44.54$ in fish from South Korea ${ }^{30}$. Our results showed that the highest average level of As $(3.172 \mathrm{mg} / \mathrm{kg}$ ) was found in flounder (Pleuronectiformes).

Arsenic can be presented in several organic (trivalent and pentavalent arsenic) and inorganic (elemental, trivalent and pentavalent arsenic) forms. Organic As showed low toxicity does not accumulate due to the rapid excretion in the human body ${ }^{31}$. Up to $90 \%$ of As in fish muscle is present in the non-toxic arsenobetain form ${ }^{32,33}$. However, according to MAC $(0.1 \mathrm{mg} / \mathrm{kg})$ for inorganic As (iAs) in China, there could be some samples exceeding the MAC in this study.

Cadmium (Cd). The concentration of $\mathrm{Cd}$ was found at the mean of $0.009 \mathrm{mg} / \mathrm{kg}$ (average range of $0.002-$ $0.040 \mathrm{mg} / \mathrm{kg}$ ). One sample (pomfret, Pampus argenteus) of 652 contained higher level than the MAC of $0.1 \mathrm{mg} /$ 


\begin{tabular}{|c|c|c|c|c|c|}
\hline & Area & $\mathbf{N}$ & Mean level (mg/kg) & Exposure ( $\mu \mathrm{g} / \mathrm{kg}$ bw/day) & References \\
\hline \multirow{7}{*}{ As } & Bangladesh (Dhaka) & - & $0.4-1.3$ & - & Rahman et al. $(2012)^{29}$ \\
\hline & Patuakhali & - & 0.3 & - & Islam et al. $(2015)^{39}$ \\
\hline & Croatia & 61 & $0.56-23.3$ & $0.2-12$ (iAs) & Juresa et al. $(2010)^{28}$ \\
\hline & China (Zhejiang) & 30 & $0.325-1.244$ & $0.6-2.3$ & Liu et al. $(2020)^{17}$ \\
\hline & South Korea & - & $1.23-44.54$ & - & Islam et al. $(2010)^{30}$ \\
\hline & China (Pearl River Delta) & 711 & $0.003-1.53$ & - & Leung et al. $(2014)^{9}$ \\
\hline & China (Zhejiang) & 643 & $0.783(0.315-3.175)$ & 1.416 & This study \\
\hline \multirow{7}{*}{$\mathrm{Cd}$} & Oman & 873 & $0.0049-0.036$ & - & Al-Busaidi et al. $(2011)^{35}$ \\
\hline & Croatia & 61 & $0.002-0.142$ & $0.1-0.2$ & Juresa et al. $(2010)^{28}$ \\
\hline & China (South China Sea) & 255 & $0.006-0.050$ & - & Gu et al. $(2017)^{34}$ \\
\hline & China (Zhejiang) & 30 & $0.004-0.007$ & $0.008-0.013$ & Liu et al. $(2020)^{17}$ \\
\hline & \begin{tabular}{|l|} 
South Korea \\
\end{tabular} & - & LOD-0.13 & - & Islam et al. $(2010)^{30}$ \\
\hline & China (Pearl River Delta) & 711 & $0.02-0.06$ & - & Leung et al. (2014) ${ }^{9}$ \\
\hline & China (Zhejiang) & 652 & $0.009(0.002-0.040)$ & 0.016 & This study \\
\hline \multirow{5}{*}{$\mathrm{Hg}$} & Oman & 873 & $0.015-0.101$ & - & Al-Busaidi et al. $(2011)^{35}$ \\
\hline & Croatia & 61 & $0.134-0.373$ & $0.2-1$ & Juresa et al. $(2010)^{28}$ \\
\hline & China (Zhejiang) & 30 & $0.002-0.008$ & $0.005-0.015$ & Liu et al. $(2020)^{17}$ \\
\hline & South Korea & - & $0.01-0.24$ & - & Islam et al. $(2010)^{30}$ \\
\hline & \begin{tabular}{|l|} 
China (Zhejiang) \\
\end{tabular} & 650 & $0.031(0.009-0.060)$ & 0.056 & This study \\
\hline \multirow{10}{*}{$\mathrm{Pb}$} & Bangladesh (Dhaka) & - & $0.4-2.1$ & - & Rahman et al. $(2012)^{35}$ \\
\hline & \begin{tabular}{|l|} 
Patuakhali \\
\end{tabular} & - & 0.7 & - & Islam et al. $(2015)^{39}$ \\
\hline & Oman & 873 & $0.029-0.196$ & - & Al-Busaidi et al. $(2011)^{35}$ \\
\hline & Croatia & 61 & $0.007-0.150$ & $0.1-0.4$ & Juresa et al. $(2010)^{28}$ \\
\hline & Italy & 41 & 0.008 & 0.003 & Malavolti et al. $(2020)^{40}$ \\
\hline & China (South China Sea) & 255 & $0.13-0.68$ & - & Gu et al. $(2017)^{34}$ \\
\hline & China (Zhejiang) & 30 & $0.004-0.014$ & $0.008-0.038$ & Liu et al. $(2020)^{17}$ \\
\hline & South Korea & - & $0.05-0.74$ & - & Islam et al. $(2010)^{30}$ \\
\hline & China (Pearl River Delta) & 711 & $0.03-8.62$ & - & Leung et al. $(2014)^{9}$ \\
\hline & China (Zhejiang) & 633 & $0.043(0.021-0.082)$ & 0.078 & This study \\
\hline \multirow{6}{*}{$\mathrm{Cr}$} & Bangladesh (Dhaka) & - & $0.09-0.4$ & - & Rahman et al. $(2012)^{29}$ \\
\hline & \begin{tabular}{|l|} 
Patuakhali \\
\end{tabular} & - & 0.7 & - & Islam et al. $(2015)^{39}$ \\
\hline & China (South China Sea) & 255 & $0.18-0.85$ & - & Gu et al. $(2017)^{34}$ \\
\hline & South Korea & - & $0.09-1.32$ & - & Islam et al. $(2010)^{30}$ \\
\hline & China (Pearl River Delta) & 711 & $0.2-0.65$ & - & Leung et al. $(2014)^{9}$ \\
\hline & China (Zhejiang) & 189 & $0.114(0.016-0.173)$ & 0.206 & This study \\
\hline
\end{tabular}

Table 3. Comparison of the levels of toxic elements in fish and exposure estimates to some previous studies.

kg. Previous report also found the average level of $0.004-0.007 \mathrm{mg} / \mathrm{kg}$ in fish samples from East China Sea ${ }^{17}$, $0.02-0.06 \mathrm{mg} / \mathrm{kg}$ in fish samples from Pearl River Delta of China ${ }^{9}, 0.006-0.050 \mathrm{mg} / \mathrm{kg}$ in fish from South China $\mathrm{Sea}^{34}$. We also found that Pacific saury (Cololabis saira) contained the highest level of Cd $(0.040 \mathrm{mg} / \mathrm{kg}) \mathrm{among}$ the 15 fish species.

Mercury (Hg). The Hg level was observed with a mean of $0.031 \mathrm{mg} / \mathrm{kg}$ (average range of $0.009-0.060 \mathrm{mg} / \mathrm{kg}$ ). Our results were lower than those reported in other areas of Croatia, Oman and South Korea, where the levels were ranged from 0.015 to $0.373 \mathrm{mg} / \mathrm{kg}^{28,30,35}$. Two fish species of Pacific Saury (Cololabis saira) and Leuciscus waleckii showed higher concentrations of $0.060 \mathrm{mg} / \mathrm{kg}$ and $0.058 \mathrm{mg} / \mathrm{kg}$ than other fishes.

Mercury is present in the environment in organic and inorganic chemical forms, each showing different characteristics including mobility and toxicity. Among these chemical forms, methylmercury (MeHg) is well-known as a serious toxicant to human body. The nervous system is the primary target organ for $\mathrm{MeHg}$ poisoning and the brain of developing fetus is more sensitive than that of the adults ${ }^{36} \mathrm{MeHg}$ generally accounts for $75-100 \%$ of the total $\mathrm{Hg}$ present in most fish species ${ }^{37}$. Furthermore, single species especially in predatory fish with older or larger body may have higher levels of accumulated $\mathrm{Hg}^{38}$. Although the level of $\mathrm{Hg}$ found in this study was low, concerns still need to be made in terms of the potential pollution.

Lead $(\mathrm{Pb})$. The mean level of $\mathrm{Pb}$ was $0.043 \mathrm{mg} / \mathrm{kg}$ (average range of $0.021-0.082 \mathrm{mg} / \mathrm{kg}$ ). According to the current MAC of $0.5 \mathrm{mg} / \mathrm{kg}$, $99.5 \%$ of total samples were acceptable on $\mathrm{Pb}$ contamination level. As shown in Table 3, the reports on $\mathrm{Pb}$ levels in fish from China varied with a great extent ${ }^{9,17,34}$. Similar levels with our data were 


\begin{tabular}{|l|l|l|l|l|l|}
\hline \multirow{2}{*}{ Sampling area } & \multicolumn{5}{|l|}{ Median $(\mathbf{P 2 5}, \mathbf{P 7 5})(\mathbf{m g} /$ kg wet weight $)$} \\
\cline { 2 - 6 } & As, & Cd & Cr & Hg & Pb \\
\hline 1 & $0.628(0.414,0.699)^{\mathrm{a}}$ & $0.008(0.002,0.009)$ & $0.112(0.075,0.177)^{\mathrm{a}}$ & $0.017(0.006,0.022)^{\mathrm{a}}$ & $0.019(0.007,0.032)^{\mathrm{a}}$ \\
\hline 2 & $0.798(0.352,0.827)^{\mathrm{b}}$ & $0.016(0.003,0.021)$ & $0.109(0.069,0.180)^{\mathrm{a}}$ & $0.034(0.018,0.041)^{\mathrm{b}}$ & $0.062(0.029,0.072)^{\mathrm{b}}$ \\
\hline 3 & $0.830(0.413,0.941)^{\mathrm{b}}$ & $0.011(0.002,0.023)$ & $0.180(0.105,0.251)^{\mathrm{b}}$ & $0.036(0.017,0.049)^{\mathrm{b}}$ & $0.055(0.031,0.076)^{\mathrm{b}}$ \\
\hline 4 & $0.867(0.379,0.957)^{\mathrm{b}}$ & $0.009(0.003,0.018)$ & $0.190(0.113,0.264)^{\mathrm{b}}$ & $0.057(0.021,0.068)^{\mathrm{b}}$ & $0.059(0.028,0.071)^{\mathrm{b}}$ \\
\hline
\end{tabular}

Table 4. Comparison of different heavy metals in marine fish from four sample areas in Zhejiang, China. Means followed by different letters $(\mathrm{a}$ and $\mathrm{b})$ in each column are significantly different $(P<0.05)$.

\begin{tabular}{|c|c|c|c|c|c|c|c|c|c|c|c|c|}
\hline & \multicolumn{2}{|c|}{$\begin{array}{l}\text { Exposure dose } \\
\text { for adults ( } \mu \mathrm{g} / \\
\mathrm{kg} \text { bw/day) }\end{array}$} & \multicolumn{2}{|c|}{ THQ for adults } & \multicolumn{2}{|c|}{ HI for adults } & \multicolumn{2}{|c|}{$\begin{array}{l}\text { Exposure dose } \\
\text { for children }(\mu \mathrm{g} / \\
\mathrm{kg} \text { bw/day) }\end{array}$} & \multicolumn{2}{|c|}{$\begin{array}{l}\text { THQ for } \\
\text { children }\end{array}$} & \multicolumn{2}{|c|}{ HI for children } \\
\hline & Mean & P97.5 & Mean & P97.5 & Mean & P97.5 & Mean & P97.5 & Mean & P97.5 & Mean & P97.5 \\
\hline As & 1.416 & 6.230 & 0.472 & 2.077 & \multirow{5}{*}{0.945} & \multirow{5}{*}{4.278} & 2.832 & 12.459 & 0.944 & 4.153 & \multirow{5}{*}{1.889} & \multirow{5}{*}{8.556} \\
\hline $\mathrm{Cd}$ & 0.016 & 0.083 & 0.020 & 0.104 & & & 0.033 & 0.166 & 0.041 & 0.208 & & \\
\hline $\mathrm{Cr}$ & 0.206 & 0.707 & 0.000 & 0.000 & & & 0.412 & 1.414 & 0.000 & 0.000 & & \\
\hline $\mathrm{Hg}$ & 0.056 & 0.250 & 0.400 & 1.783 & & & 0.112 & 0.499 & 0.801 & 3.565 & & \\
\hline $\mathrm{Pb}$ & \begin{tabular}{|l|}
0.078 \\
\end{tabular} & 0.472 & 0.052 & 0.315 & & & 0.156 & 0.944 & 0.104 & 0.629 & & \\
\hline
\end{tabular}

Table 5. Estimated exposures to $\mathrm{As}, \mathrm{Cd}, \mathrm{Cr}, \mathrm{Hg}$ and $\mathrm{Pb}$ for consumption of marine fish from Zhejiang province.

reported by Liu et al. ${ }^{17}$. In some polluted area, such as Patuakhali, mean Pb level was as high as $0.7 \mathrm{mg} / \mathrm{kg}^{39}$. Low level of $\mathrm{Pb}(0.008 \mathrm{mg} / \mathrm{kg})$ in fish from Italy was observed ${ }^{40}$.

Lead is one of the main pollutants in the environment and naturally occurs in rocks, soils and in the hydrosphere. Once discharged into the marine environment, $\mathrm{Pb}$ is easily absorbed by fish and accumulated in the body tissues, bones, gills, kidneys, liver and scales ${ }^{41}$. Our results showed that different fishes accumulated diverse lead concentrations.

Chromium (Cr). Average concentration of $\mathrm{Cr}$ in analyzed fish was $0.114 \mathrm{mg} / \mathrm{kg}$ (average range of $0.016-$ $0.173 \mathrm{mg} / \mathrm{kg}$ ). High mean levels for Cr were found in pomfret (Pampus argenteus) with $0.173 \mathrm{mg} / \mathrm{kg}$, sea bass (Lateolabrax japonicas) with $0.71 \mathrm{mg} / \mathrm{kg}$ and little yellow croaker (Larimichthys polyactis) with $0.17 \mathrm{mg} / \mathrm{kg}$. Our results were lower than those found in other place of China which showed $0.18-0.85 \mathrm{mg} / \mathrm{kg}$ in South China Sea and $0.2-0.65 \mathrm{mg} / \mathrm{kg}$ in Pearl River Delta ${ }^{9,34}$. In South Korea, the Cr concentrations in fish were 0.08-1.32 mg/ $\mathrm{kg}^{30}$.

Comparison of heavy metals in different sampling areas. As shown in Table 4, levels of As, Cd, Cr, $\mathrm{Hg}$ and $\mathrm{Pb}$ in marine fish from four areas (1, 2, 3 and 4) were compared. For $\mathrm{As}, \mathrm{Hg}$ and $\mathrm{Pb}$ mean levels in area 1 were significantly lower than the other sampling areas $(P<0.05)$. Cr levels in area 1 and 2 were obviously lower than area 3 and $4(P<0.05)$. There were no statistical difference for Cd levels in four sampling areas $(P>0.05)$. It indicates that the heavy metals contaminated in marine fish may derive from different sources.

Estimated daily intake (EDI) of heavy metals. The EDIs of adults were showed in Table 5. The 97.5th percentile (P97.5) level was used to represent the high exposed consumers of the distribution. The mean intakes of $\mathrm{As}, \mathrm{Cd}, \mathrm{Cr}, \mathrm{Hg}$ and $\mathrm{Pb}$ through marine fish were estimated to be $1.214,0.014,0.177,0.048$, and $0.037 \mu \mathrm{g} / \mathrm{kg}$ bw/day. The P97.5 daily intakes of As, $\mathrm{Cd}, \mathrm{Hg}$ and $\mathrm{Pb}$ were $5.34,0.071,0.606,0.214$, and $0.405 \mu \mathrm{g} / \mathrm{kg}$ bw/day. Our results of mean EDIs were similar with the study of Liu et al. ${ }^{17}$, and lower than the report of Rahman et al..$^{29}$. Comparing with the recommended safe value (showed in Table 5), the P97.5 daily intakes of As exceeded the safe limit. It indicates that the long-term large consumption of marine fish may have potential health risk for As in Zhejiang.

Health risk assessment. The targeted hazard quotient (THQ) and hazard index (HI) was used for the risk assessment. The recommended reference doses (RfDs) or safe values were based on previous report ${ }^{2}$. As shown in Table 5, for the mean exposure, the data of THQs for both adults and children were all less than 1, which indicated that there was no potential health risk to general people. However, the THQ for As and $\mathrm{Hg}$ at the high exposure level (P97.5) was more than 1. HI calculated by the sum of THQ was adopted for estimating the total risk of these elements. The value of $\mathrm{HI}$ at mean exposure level for children was more than 1 . Concerns might be paid for the high exposure of these elements by the fish consumption. 


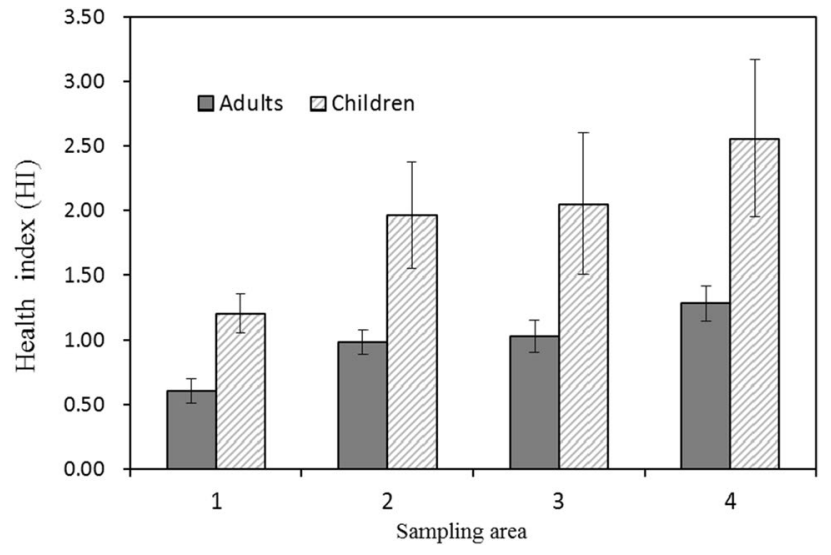

Figure 3. The health index (HI) of heavy metals for adults and children in different sampling areas (mean \pm standard error).

The difference of HI (mean level) for adults and children in different sampling areas was investigated. As shown in Fig. 3, HIs for adults and children in sampling area 1 were obviously lower than other sampling areas $(P<0.05)$. There were no obvious difference for HIs among sampling areas 2,3 and $4(P>0.05)$.

It should be noted that coastal area of China are now facing great challenges in regard to heavy metal contamination $^{42}$. Zhejiang coastal area is typical transitional zone between land and ocean, receiving a large amount of anthropogenic pollutants ${ }^{43}$. Our findings are consistent with previous studies on the coast of Zhejiang, indicating that $\mathrm{As}, \mathrm{Pb}$, and $\mathrm{Cd}$ are the main pollutants ${ }^{14}$.

Furthermore, the THQ and HI widely used for evaluation of the health risk has some obvious shortages ${ }^{42}$ : (1) Only determined targets are considered while the other potential hazardous pollutants are ignored; (2) The mutual effects of selected pollutants are ignored for calculating the THQ. (3) The toxicities of heavy metals are related with their chemical forms ${ }^{44,45}$. For example, methylmercury (MeHg), inorganic arsenic, $\mathrm{Cr}(\mathrm{VI})$ in aquatic organisms showed higher toxicity than their other forms. There are still some limitations in this study. For example, vulnerable populations (e.g. pregnant women) and other exposure pathway were not considered here. Therefore, the current risk assessment method for heavy metals might be improved in the further.

\section{Conclusion}

The mean levels of $\mathrm{As}, \mathrm{Cd}, \mathrm{Cr}, \mathrm{Hg}$ and $\mathrm{Pb}$ in marine fish collected from coastal area of Zhejiang (located in southeast of China) were all below their MAC of China. The risk assessment showed that mean daily exposures of these elements by marine fish consumption were lower than the reference values of JECFA, EPA or EFSA. We concluded that the consumption of marine fish from Zhejiang had low health risk to general people. However, considering the high exposure level (the P97.5 estimation), the HI of all elements was more than 1, which indicated consumers especial vulnerable populations (e.g. children, pregnant women) may experience some adverse health effects.

Accordingly, the regular monitoring of heavy metals and metalloid elements in fish is recommended in this area. We will investigate the possible sources of toxic elements in marine fish and their distribution in fish bodies in our future studies.

Received: 2 February 2021; Accepted: 11 May 2021

Published online: 26 May 2021

\section{References}

1. Wang, C., Zou, X., Feng, Z., Hao, Z. \& Gao, J. Distribution and transport of heavy metals in estuarine-inner shelf regions of the East China Sea. Sci. Total Environ. 644, 298-305 (2018).

2. Bosch, A. C., O’Neill, B., Sigge, G. O., Kerwath, S. E. \& Hoffman, L. C. Heavy metals in marine fish meat and consumer health: A review. J. Sci. Food Agric. 96, 32-48 (2016).

3. Filippini, T. et al. Intake of arsenic and mercury from fish and seafood in a Northern Italy community. Food Chem. Toxicol. 116, 20-26 (2018).

4. Ferrante, M. et al. Systematic review of arsenic in fresh seafood from the Mediterranean Sea and European Atlantic coasts: A health risk assessment. Food Chem. Toxicol. 126, 322-331 (2019).

5. Copat, C. et al. Trace elements in seafood from the Mediterranean sea: An exposure risk assessment. Food Chem. Toxicol. 115, 13-19 (2018).

6. Tarley, C. R., Coltro, W. K., Matsushita, M. \& de Souza, N. E. Characteristic levels of some heavy metals from Brazilian canned sardines (Sardinella brasiliensis). J. Food Compos. Anal. 14, 611-617 (2001).

7. Ogundiran, M., Adewoye, S., Ayandiran, T. \& Dahunsi, S. Heavy metal, proximate and microbial profile of some selected commercial marine fish collected from two markets in south western Nigeria. Afr. J. Biotechnol. 13, 1147-1153 (2014).

8. Marcotrigiano, G. \& Storelli, M. Heavy metal, polychlorinated biphenyl and organochlorine pesticide residues in marine organisms: Risk evaluation for consumers. Vet. Res. Commun. 27, 183-195 (2003).

9. Leung, H. et al. Assessment of heavy metals/metalloid ( $\mathrm{As}, \mathrm{Pb}, \mathrm{Cd}, \mathrm{Ni}, \mathrm{Zn}, \mathrm{Cr}, \mathrm{Cu}, \mathrm{Mn}$ ) concentrations in edible fish species tissue in the Pearl river delta (PRD), China. Mar. Pollut. Bull. 78, 235-245 (2014). 
10. EFSA. Scientific opinion of the Panel on Contaminants in the Food Chain on a request from the European Commission on cadmium in food. EFSA J. 980, 1-139 (2009).

11. Carocci, A., Rovito, N., Sinicropi, M. S. \& Genchi, G. Mercury toxicity and neurodegenerative effects. Rev. Environ. Contamination Toxicol. 229, 1-18 (2014).

12. Raj, D. \& Maiti, S. K. Sources, bioaccumulation, health risks and remediation of potentially toxic metal (loid) s (As, Cd, Cr, $\mathrm{Pb}$ and Hg): An epitomised review. Environ. Monit. Assess. 192, 1-20 (2020).

13. Huang, Z. et al. Determination of methylmercury in marine fish from coastal areas of Zhejiang, China. Food Addit. Contaminants Part B 5, 182-187 (2012).

14. Yang, H. et al. An improved weighted index for the assessment of heavy metal pollution in soils in Zhejiang, China. Environ. Res. 192, $110246(2020)$.

15. Jiang, Q., He, J., Ye, G. \& Christakos, G. Heavy metal contamination assessment of surface sediments of the East Zhejiang coastal area during 2012-2015. Ecotoxicol. Environ. Saf. 163, 444-455 (2018).

16. Liang, J., Liu, J., Xu, G. \& Chen, B. Distribution and transport of heavy metals in surface sediments of the Zhejiang nearshore area, East China Sea: Sedimentary environmental effects. Mar. Pollut. Bull. 146, 542-551 (2019).

17. Liu, Q. et al. Heavy metal concentrations in tissues of marine fish and crab collected from the middle coast of Zhejiang Province, China. Environ. Monit. Assess. 192, 1-12 (2020).

18. Mangalagiri, P., Bikkina, A., Sundarraj, D. K. \& Thatiparthi, B. R. Bioaccumulation of heavy metals in Rastrelliger kanagurta along the coastal waters of Visakhapatnam, India. Mar. Pollut. Bull. 160, 111658 (2020).

19. Keshavarzi, B. et al. Heavy metal contamination and health risk assessment in three commercial fish species in the Persian Gulf. Mar. Pollut. Bull. 129, 245-252 (2018).

20. Hossain, M. B., Shanta, T. B., Ahmed, A. S., Hossain, M. K. \& Semme, S. A. Baseline study of heavy metal contamination in the Sangu River estuary, Chattogram, Bangladesh. Mar. Pollut. Bull. 140, 255-261 (2019).

21. WHO. Reliable evaluation of low-level contaminants of food. Workshop in the frame of GEMS/Food-EURO, Kulmbach, Germany, 26-27 May 1995 (1995).

22. Chen, Q., Pan, X.-D., Huang, B.-F. \& Han, J.-L. Distribution of metals and metalloids in dried seaweeds and health risk to population in southeastern China. Sci. Rep. 8, 1-7 (2018).

23. Huang, Z., Pan, X.-D., Wu, P.-G., Han, J.-L. \& Chen, Q. Health risk assessment of heavy metals in rice to the population in Zhejiang, China. PLoS ONE 8, e75007 (2013).

24. Huang, Z., Pan, X.-D., Wu, P.-G., Han, J.-L. \& Chen, Q. Heavy metals in vegetables and the health risk to population in Zhejiang, China. Food Control 36, 248-252 (2014).

25. USEPA. Concepts, methods, and data sources for cumulative health risk assessment of multiple chemicals, exposures and effects: a resource document (US Environmental Protection Agency, 2007).

26. WHO. Joint FAO/WHO consultation on food consumption and exposure assessment to chemicals in food. Geneva, Switzerland, 10-14 February 1997 (1997).

27. MHPRC (Ministry of Health of the People's Republic of China). Maximum Levels of Contaminants in Foods (GB2762-2017) (MHPRC, Beijing, 2017) (in Chinese).

28. Jureša, D. \& Blanuša, M. Mercury, arsenic, lead and cadmium in fish and shellfish from the Adriatic Sea. Food Addit. Contam. 20, 241-246 (2003).

29. Rahman, M. S., Molla, A. H., Saha, N. \& Rahman, A. Study on heavy metals levels and its risk assessment in some edible fishes from Bangshi River, Savar, Dhaka, Bangladesh. Food Chem. 134, 1847-1854 (2012).

30. Islam, M., Bang, S., Kim, K.-W., Ahmed, M. \& Jannat, M. Heavy metals in frozen and canned marine fish of Korea. J. Sci. Res. 2, $549-549(2010)$.

31. Taylor, V. et al. Human exposure to organic arsenic species from seafood. Sci. Total Environ. 580, 266-282 (2017).

32. Koesmawati, T. A., Buchari, B., Sulaeman, A. \& Ibrahim, S. Sample preparation methods for organic arsenic species (arsenobetain, (CH3) 3As+ $\mathrm{CH} 2 \mathrm{COO}-$ ) in tuna fish samples followed by HG-QFAAS, GF-AAS, and ICP-MS measurements. Procedia Chem. 17, 200-206 (2015).

33. Cava-Montesinos, P., Nilles, K., Cervera, M. L. \& de la Guardia, M. Non-chromatographic speciation of toxic arsenic in fish. Talanta 66, 895-901 (2005).

34. Gu, Y.-G. et al. Heavy metals in fish tissues/stomach contents in four marine wild commercially valuable fish species from the western continental shelf of South China Sea. Mar. Pollut. Bull. 114, 1125-1129 (2017).

35. Al-Busaidi, M. et al. Toxic metals in commercial marine fish in Oman with reference to national and international standards. Chemosphere 85, 67-73 (2011).

36. Clarkson, T. W., Magos, L. \& Myers, G. J. The toxicology of mercury-Current exposures and clinical manifestations. N. Engl. J. Med. 349, 1731-1737 (2003).

37. Burger, J. \& Gochfeld, M. Mercury in canned tuna: white versus light and temporal variation. Environ. Res. 96, 239-249 (2004).

38. Boening, D. W. Ecological effects, transport, and fate of mercury: A general review. Chemosphere 40, 1335-1351 (2000).

39. Islam, M. S., Ahmed, M. K. \& Habibullah-Al-Mamun, M. Determination of heavy metals in fish and vegetables in Bangladesh and health implications. Hum. Ecol. Risk Assess. Int. J. 21, 986-1006 (2015).

40. Malavolti, M. et al. Lead exposure in an Italian population: Food content, dietary intake and risk assessment. Food Res. Int. 137, 109370 (2020).

41. Nussey, H. Bioaccumulation of chromium, manganese, nickel and lead in the tissues of the moggel, Labeo umbratus (Cyprinidae), from Witbank Dam, Mpumalanga. Water Sa 26, 269-284 (2000).

42. Wang, S.-L., Xu, X.-R., Sun, Y.-X., Liu, J.-L. \& Li, H.-B. Heavy metal pollution in coastal areas of South China: A review. Mar. Pollut. Bull. 76, 7-15 (2013).

43. Zhang, M., Sun, X. \& Xu, J. Heavy metal pollution in the East China Sea: A review. Mar. Pollut. Bull. 159, 111473 (2020).

44. Filippini, T. et al. Diet composition and serum levels of selenium species: A cross-sectional study. Food Chem. Toxicol. 115, 482-490 (2018).

45. Adel, M. et al. Bioaccumulation of trace metals in banded Persian bamboo shark (Chiloscyllium arabicum) from the Persian Gulf: A food safety issue. Food Chem. Toxicol. 113, 198-203 (2018).

\section{Acknowledgements}

The authors would like to thank many colleagues in CDC of Zhejiang provincial cities for their laboratory analysis.

\section{Author contributions}

X.-D.P., and Q.C. conceived the experiment(s), X.-D.P., Q.C. and B.-F.H. conducted the experiment(s), X.-D.P., Q.C., B.-F.H. and J.-L.H. analyzed the results. All authors reviewed the manuscript. 


\section{Competing interests}

The authors declare no competing interests.

\section{Additional information}

Correspondence and requests for materials should be addressed to X.-D.P.

Reprints and permissions information is available at www.nature.com/reprints.

Publisher's note Springer Nature remains neutral with regard to jurisdictional claims in published maps and institutional affiliations.

(c) (i) Open Access This article is licensed under a Creative Commons Attribution 4.0 International License, which permits use, sharing, adaptation, distribution and reproduction in any medium or format, as long as you give appropriate credit to the original author(s) and the source, provide a link to the Creative Commons licence, and indicate if changes were made. The images or other third party material in this article are included in the article's Creative Commons licence, unless indicated otherwise in a credit line to the material. If material is not included in the article's Creative Commons licence and your intended use is not permitted by statutory regulation or exceeds the permitted use, you will need to obtain permission directly from the copyright holder. To view a copy of this licence, visit http://creativecommons.org/licenses/by/4.0/.

(c) The Author(s) 2021 